\title{
Reform and Development Path of Innovation and Entrepreneurship Education in Local Application-Oriented Colleges and Universities
}

\author{
Cui Wenyi \\ Department of Structural Engineering \\ Yanbian University \\ Yanji,China \\ cuiwy@ybu.edu.cn
}

\begin{abstract}
Firstly, this paper briefly summarizes and analyzes the concept and main characteristics of innovation and entrepreneurship education in local application oriented colleges and universities. And it takes them as the sample of reforming and developing the innovation and entrepreneurship education in local application-oriented colleges and universities in our country through learning from the development of the innovation and entrepreneurship education in international advanced countries and analyzing their characteristics. The paper finds out the constraints that constraint the development of innovation and entrepreneurship education in local application-oriented colleges and universities in our country by analyzing the current situation and the problems emerged in the development process. And it discusses the reform strategy and development path to develop smoothly the innovation and entrepreneurship education in local application-oriented colleges and universities in our country from several specific aspects, such as, the development direction and goal of the innovation and entrepreneurship education, the perfection and reform of management system, change of evaluation ways, and transformation of the direction of teacher training.
\end{abstract}

Keywords-innovation and entrepreneurship education; local application-oriented universities; reference; countermeasures; ways.

\section{INTRODUCTION}

It is well known that, in our country, the local application-oriented colleges and universities take the important mission of cultivating all kinds of innovative talents needed by the socialism construction. Therefore, it must be the long-term development goals of the local application-oriented colleges and universities to develop college students' ability of innovation and entrepreneurship. The essence of the so-called innovation and entrepreneurship education is to improve the quality of the education objects. Only the talents who have the innovative and entrepreneurial spirits have their own innovative consciousness and innovative spirit. We should develop and cultivate people's creative potential and promote people' $s$ quality developing towards the direction of innovative talent by innovating modern scientific culture, exciting the creative ability and training the creative thinking, whose inner core is to cultivate innovative consciousness and entrepreneurial spirit.

\author{
Li BaiShou* \\ Department of Structural Engineering \\ Yanbian University \\ Yanji,China \\ bsli@ybu.edu.cn \\ * Corresponding Author
}

\begin{abstract}
II. THE DEVELOPMENT OF INNOVATION AND ENTREPRENEURSHIP EDUCATION IN THE DEVELOPED COUNTRIES AND THE ENLIGHTENMENT TO THE INNOVATION AND ENTREPRENEURSHIP EDUCATION IN LOCAL APPLICATION-ORIENTED COLLEGES AND UNIVERSITIES IN CHINA
\end{abstract}

In the beginning, innovation and entrepreneurship education emerged in some enterprise training in the developed countries, and later gradually widely applied in the regular education in colleges and universities. Started from 1970s, innovation and entrepreneurship education in the developed countries have developed obviously gradually stepped towards the normal.

\section{A. The Development History of Innovation and Entrepreneurship Education in the Developed Countries}

First of all, the United States was the first country to carry out innovation and entrepreneurship education, further, the education reform has become an important measure for the United States to deal with various national crises. At the beginning, the education reform in American began in 1957 when the Soviet Union launched the manmade satellite. The United States felt a strong crisis under the impact of technological development in other countries, so it promulgated laws related to defense education next year whose main purpose is to promote the domestic education in the United States adapting to the national defense education to deal with the international situation changes. As early as 1973, the United States created a innovation and entrepreneurship education center gathered by four well-known colleges and universities to carry out innovation and entrepreneurship education and all kinds of innovation and entrepreneurship experiments. In the following few years, other colleges and universities in American also began to popularize the innovation and entrepreneurship education, and then innovation and entrepreneurship education bloomed and bear fruits rapidly in colleges and universities in the United States. 1980s, when Japan began to become the world leader in the field of electronic science and technology, which gave the United States a huge pressure, the United States realized that under-developed education will threaten the whole country's economic security gradually. Therefore, it began to establish the national education system again. 1983, the United States began to improve the quality of higher 
education which aimed to cultivate more talents with innovative ability, explorative spirit and investigation practice spirit. In 2000, the United States pointed out in the education plan that education must be put on the first place, and this showed that there was a long history that education had an important position in the domestic America.

Secondly, Japan has already had the goal of surpassing the western developed countries in the early period of the Meiji Restoration and used education as an important weapon to achieve this goal. The modern Nihon University began in the late nineteenth Century, and its development has played a very important role in promoting its pre war economic construction and the post-war economic recovery. In the eighties of last century, Japan's economic status and technological status in the world have been promoted to a new situation, and it gradually created a new way of innovation and entrepreneurship education belong to Japan. In the late 80's, Japan began to formulate its own educational goals in 21 Century actively to promote the cultivation of domestic talents, and it aimed to heighten the students' creativity and innovative spirit to a new level and promote the formation of students' scientific literacy.

Thirdly, German education occupied the highest position in the whole European history and many forms of western education emerged in Germany. After the Second World War, the educational atmosphere of German colleges and universities emphasized the freedom of academic and the integration between science and technology research and education, and it started to develop innovation and entrepreneurship education within colleges and universities. Started from 1976, the core of German education was to emphasize exploiting the potential of college students, and it took the cultivation of innovative talents as an important task of higher education. It paid attention to the cultivation of college students' personality, the sense of responsibility and critical ability so that they stand firmly in the fierce international competition. At the present stage, the education system of the German university takes the cultivation of quality as the basis of education. Colleges and universities, governments and the community all take the cultivation of innovation and entrepreneurship ability as an important task of personnel training.

\section{B. The Enlightenment to the Innovation and Entrepreneurship Education in Local Application-Oriented Colleges and Universities in China from International Advanced Experiences}

From the advanced teaching idea and experience, we can see that the innovation and entrepreneurship education in colleges and universities in our country must follow the footsteps of the developed countries in the world. We should improve the degree of attention to education actively, and strive to reform the education system and popularize innovation and entrepreneurship education to develop them extensively in local application-oriented colleges and universities in China. First, all countries in the world realize that the innovation and entrepreneurship education can promote the overall quality of the whole nation, it can be advantageous to improve the international competitiveness of the country and beneficial to stabilize the country's position in the world. Therefore, it is necessary for China to realize the important mission of developing innovation and entrepreneurship education as well as improving education quality. Second, the innovation and entrepreneurship education reform must be sustained. Started from 1980s, educational reform in each country emerges in an endless stream. Because of the complexity and seriousness of education, reform is a longterm and arduous task which cannot be completed in a short time. Third, the improvement and adjustment of education regulation and education system is the most important task in the 21 century for each country. China also must follow the footsteps of the developed countries in the world and perfect domestic education system actively. Fourth, the focus of education is to improve the quality of education. At the same time when we increase the number of colleges and universities and the number of students, we also must improve the quality. Fifth, we should improve the curriculum structure, adjust the overall goal and put the science and technology on the important position. Only the scientific and technological level stand in the advanced rank in the world, our country's comprehensive national strength can be improved and then can make China stand in an invincible position in the fierce international competition.

\section{REFORM COUNTERMEASURES AND DEVELOPMENT PATH OF INNOVATION AND ENTREPRENEURSHIP \\ EDUCATION IN LOCAL APPLICATION-ORIENTED COLLEGES AND UNIVERSITIES IN CHINA}

It must be the main content of the education reform that the transformation of educational idea in colleges and universities in our country from the traditional to the innovative. The cultivation of innovative talents is an important task for local application-oriented colleges and universities in the present stage.

\section{A. Making Sure the Fundamental Goal of Innovation and Entrepreneurship Education in Local Colleges and Universities in China, and Fixing the Value Orientation on the Cultivation of Innovative Talents.}

The main purpose of innovation and entrepreneurship education is to cultivate innovative and entrepreneurial talents who can adapt to the modern social development and reform and who have distinct time characteristic. Its goal is principal, guiding, practical and comprehensive, and the principle the target design followed is clear, feasible, and hierarchical. Therefore, the focus of innovation and entrepreneurship education in colleges and universities in our country is to stimulate college students creativity, and cultivate the new type compound talents with comprehensive qualities. Therefore, it must be the fundamental goal of the innovation and entrepreneurship education in our country to cultivate compound talents with innovative spirits and practical ability. In addition, according to their own position and the idea of running a school, each college and university should analyze its own advantages and target system, carry out the transformation of educational ideas, and truly implement the goal on the specific educational behaviors. 


\section{B. Promoting the Perfection of the Education} System and Management System in Local Application-Oriented Colleges and Universities in China Actively to Realize the Improvement of the Environment of Innovation and Entrepreneurship Education

In order to make the management system of colleges and universities in our country be reformed, and establish a system of local application-oriented colleges and universities which is suitable for the practical situation of China and has Chinese characteristic, we must pay attention to strengthen the vitality of colleges and universities. Administrative management is the main reason for the lack of vitality of colleges and universities in our country, and the removal of administrative management requires the government to make policy decisions as soon as possible to divide rights to each college and university gradually, such as administrative management of government to university, regulation of educational mechanism, the development rules of innovation and entrepreneurship education, etc. Only local application-oriented colleges and universities have independent rights and their education system transform towards decentralization, it can give full play to the leading role of each college and university and be conducive to improve the environment of innovation and entrepreneurship education.

\section{Further Promoting the Improvement of the Evaluation Method of Innovation and Entrepreneurship Education, and Focusing on the Improvement of Students' Innovation and Entrepreneurship}

Innovation and entrepreneurship education attach great importance to the development of students' personality and the cultivation of interest to inspire students to think independently so as to develop their critical thinking. In addition, the relationship between teachers and students must be changed from the former authority to the independent, and an independent, democratic, harmonious and friendly relationship between teachers and students must be established. Teachers and students must respect each other, listen to each other's views and respect each other's choice. Colleges and universities should pay more attention to widen students' knowledge range, cultivate and improve students' innovative consciousness, and provide more practice opportunities for students to develop and improve their innovative ability. Colleges and universities also should improve the evaluation method, ban the old evaluation system which hinders the development of innovative and entrepreneurial thinking and consciousness and transform the evaluation sight to give full play to the supervision and guidance of the evaluation and truly make evaluation improve the innovation ability.

\section{To Improve the Overall Quality of Teachers in Colleges and Universities and Teachers' Ability of Innovation and Entrepreneurship Education}

It can be imagined that the cultivation and improvement of teachers' innovative and entrepreneurial ability is one of the promotion of innovative education.
Therefore, it is beneficial to promote and impact the students positively to excite the innovative and entrepreneurial ability and enthusiasm of teachers. Innovation and entrepreneurship education itself needs the new era teachers with innovative and entrepreneurial spirits. We should strengthen the training of teachers in various creative educational position to reform and perfect teachers' professional spirit and educational philosophy, actively build new knowledge structure which is suitable for modern innovation and entrepreneurship education to promote the improvement of their own scientific research ability and education technology, and actively absorb and learn from the advanced educational ideas and methods to stand at the forefront of innovation and entrepreneurship education and provide good service for students' innovation and entrepreneurship education.

\section{E. To Strengthen the Training of Students, Practical Ability and Open Education in Local Application-Oriented Colleges and Universities}

Innovation and entrepreneurship education is a kind of open education pattern breaking through traditional English education and closed education model, and there is direct relationship between the effectiveness of innovative education and the number of students' practical activities, therefore, one-way passive education mode must be changed in daily teaching in colleges and universities. It should add more practical education in colleges and universities, and transform the passive acceptance of traditional education into a two-way interactive educational model between teachers and students, and combine theoretic knowledge with practical application tightly. In the course of teaching, the communication between teachers and students strengthens the interest and pertinence of teaching and improves students' enthusiasm of study, which is conducive to form the cube model in students' thinking and conducive to improve students' ability of innovation and entrepreneurship.

\section{F. To Overcome the Constraints of Innovation and Entrepreneurship Education in Our Country Actively, and to Improve the Curriculum Setting in Colleges and Universities}

Colleges and universities should turn original mechanical reproduction into practical application course with more innovative spirits by abandoning the traditional doctrine that lack of courage, changing actively and perfecting the curriculum in colleges and universities, and should increase the injection of adventurous spirit to create a completely new type of curriculum in local applicationoriented colleges and universities in China. And it should combine the knowledge in books and practical application organically to provide students more opportunities to show themselves and actively innovate, and to create better environment for the cultivation of new innovative talents.

\section{CONCLUSIONS}

Above all, because of our country's innovation and entrepreneurship education started late, although in the past twenty years it has achieved initial results, there are still many problems needed to be resolved and analyzed urgently. First of all, in the process of innovation and entrepreneurship education, target and positioning need to 
be further clarified. Secondly, it should pay attention to the improvement of the knowledge breadth of the local application-oriented colleges and universities in our country to provide a broad space for the innovation and entrepreneurship education. Thirdly, it should increase the bran-new practice link. Fourthly, it should improve the education evaluation system and pay attention to the students' personalized needs. Only by combining the specific problems emerged in innovation and entrepreneurship education of local application-oriented colleges and universities and real situation in our country, absorbing and learning from international advanced idea and mode, and finding out, reforming and perfecting the main factors that restrict the development of innovation and entrepreneurship education in local applicationoriented colleges and universities in China, it can improve effectively the current situation of innovation and entrepreneurship education, strengthen the comprehensive ability of education in our country, and strengthen our country, s technological power and comprehensive competitiveness to stand on an invincible position in the fierce international competition.

\section{REFERENCES}

[1] PENG Qinge, ZHU Xifang, FANG Rujian. On the Construction of Innovation and Entrepreneurship Education System in Local Undergraduate Colleges.[J] Huaihai Institute of Techology Journal: Humanities and Social Sciences Edition,2011.

[2] LU Shujing. The Principle and Mechanism of Innovation and Entrepreneurship Education Implanted into Professional Education.[J] Explore,2015.

[3] ZHANG Xin, DU Guojuan. On the Effective Path of Innovation and Entrepreneurship Training of Applied Talents in Local Undergraduate Colleges in Western China.[J] Normal University Journal,2014. 